\title{
Water Quality Assessment of the Surface Water of the Southern Bug River Basin by Complex Indices
}

\author{
Iryna Shakhman', Anastasiia Bystriantseva ${ }^{1 *}$ \\ 1 Kherson State University, Universitetska Str., 27, Kherson, 73000, Ukraine \\ *Corresponding author's e-mail: abystryantseva@ksu.ks.ua
}

\begin{abstract}
The article describes modern anthropogenic load on the surface water of the Southern Bug River Basin in a changing climate. The main water users-pollutants of the Southern Bug River Basin in Vinnytska and Mykolaivska regions were identified. The water quality of the surface water of the Southern Bug River in time and space (along the river stream) was analyzed. The water quality of the Southern Bug River was assessed by complex indices for different water users. In order to assess water quality, it is recommended to use complex indices that take into account the effect of the total action of pollutants. The self-purification potential and capability of restoration in space (along the river stream) of the aquatic ecosystem of the Southern Bug River was established for 2019. The results of the study allow us to state that the use of surface water of the Southern Bug River Basin for drinking, fishery, cultural and recreational needs is related to certain environmental risks. It is recommended to carry out the environmental protection measures aimed at adjusting the priorities of economic activity, reduction of wastewater discharge and increase in the water content of the river by regulating the operation of energy complexes.
\end{abstract}

Keywords: the Southern Bug River, water quality, surface water, pollutants, complex indices, hydrochemical parameters

\section{INTRODUCTION}

Surface water is a special natural resource of strategic importance for any state. It determines the development trends in all sectors of the economy. The greatest significance for the national economy corresponds to the surface sources of fresh water. By volume of internal freshwater resources in recalculation per capita, out of the European countries, the indicators are lower than in Ukraine only in Moldova. Ukraine is characterized by extremely high indicators of water use: $100 \%$ of technogenic transformation of surface water and $10-20 \%$ of underground water. Scientifically unjustified anthropogenic load, enhanced by climate change, led to rivers quantitative and qualitative degradation. The water quality problem is seen as the most important social, scientific and technological problem of our time, the solution to which largely depends on the correct management of water systems. Therefore, it is relevant to study the quality of surface water in order to predict the changes in the hydroecosystem condition and reduce risks of unsustainable exploitation of water by different water users.

The Southern Bug River is one of the large rivers of Ukraine. The river is located in the south-west of the country. The river originates on the Volyn-Podilska Highlands and flows into the Dnipro-Buzky Firth. The Southern Bug River Basin crosses the forest steppe and steppe areas of Ukraine, it is located in two geomorphological regions - the upper and middle parts are located on the Volyn-Podilska Highlands and the Dnieper Highlands, lower part - on the Black Sea Lowlands. The catchment of the river is completely located on the territory of Ukraine and its area $63700 \mathrm{~km}^{2}$, the length of the river is $806 \mathrm{~km}$, the fall of the river is $328 \mathrm{~m}$, the average stream gradient is $0.4 \%$. High degree of regulation of flow, several large cities, energy and industrial facilities, developed agricultural sector exert a 
significant anthropogenic load on the river, which in the first place, leads to a water quality change.

The Southern Bug River Basin is administratively located mainly within Vinnytska (62\% of the territory of the region) [Basin Administration of Water Resources of the Southern Bug River] and Mykolaivska (59.5\%) [Regional office of water resources in the Mykolaivska region] regions. The main source of water supply for the population of the regions is a river runoff. The average indicator of provision with annual runoff per one citizen of Ukraine in a dry year is 0.67 thousand $\mathrm{m}^{3} /$ year, per one citizen of the Vinnytska region 0.75 thousand $\mathrm{m}^{3} /$ year (by local runoff) [Regional report on the state of the environment in the Vinnytska region in 2018, 2019], per one citizen of the Mykolaivska region -0.26 thousand $\mathrm{m}^{3} /$ year [Regional report on the state of the environment in the Mykolaivska region in 2018, 2019].

The Southern Bug River Basin is mostly plowed. There are 16 dams on the Southern Bug River and its tributaries. There are 169 reservoirs, 10.29 thousand ponds, 50 small HPS in the basin of the river. The total volume of man-made water bodies is $1.53 \mathrm{~km}^{3}$, which exceeds the river runoff in dry years (which was $1.03 \mathrm{~km}^{3}$ in 2015) [Basin Administration of Water Resources of the Southern Bug River]. Under low-water conditions such amount of man-made water bodies increases the negative impact of economic activity on the stream-flow regime and its sanitary state.

The territory of the Southern Bug River Ba$\sin$ is inhabited by 3.24 million people; the urban population is 1.87 million people $(58 \%)$; whereas the rural population is 1.37 million people ( $42 \%)$. A centralized collection and accounting of municipal wastewater is carried out from 102 cities in 38 settlements (37\%). From 2864 villages such accounting is performed only in $10(0.3 \%)$.

The current water management situation in the Southern Bug River Basin shows more than 4 times reduction of water intake volume. In 1995 it was 1.185 billion $\mathrm{m}^{3}$, in $2019-279.2$ million $\mathrm{m}^{3}$. The total volume of water intake from surface and underground sources of the Southern Bug River Basin on the territory of the Vinnytska region in 2019 was 94.5 million $\mathrm{m}^{3}$, for the Mykolaivska region the volume was 103.8 million $\mathrm{m}^{3}$ [Basin Administration of Water Resources of the Southern Bug River, Regional office of water resources in the Mykolaivska region]. The water use by surface sources of fresh water provided in the Mykolaivska region by $93 \%$, in Vinnytska $-89 \%$.
The dominant industries of water intake of the Southern Bug River Basin are agriculture (39\%), industry (37\%), utilities (23\%). The largest water users and pollution sources of the surface water of the Southern Bug River Basin are: "South Ukrainian NPP" power plant, which uses $23 \%$ of water from all water intakes over the basin (in 2019, it amounted to 63.1 million $\mathrm{m}^{3}$ ), "Vinnytsiavodokanal" KP, which takes $12 \%$ from water intakes over the basin (33.5 million $\mathrm{m}^{3}$ in 2019), as well as Ladyzhinska heat power plant (5\% - 13.6 million $\mathrm{m}^{3}$ ), and LLC "Vinnytska poultry factory" $\left(2 \%-5.5\right.$ million $\left.\mathrm{m}^{3}\right)$.

The wastewater volume in surface water bodies in the Southern Bug River Basin in 2019 was 166.3 million $\mathrm{m}^{3}$. In overall wastewater volume in 2019 , the greatest part was met the non-contamination standards without water treatment $(56 \%)$. The contaminated effluents constituted $2 \%$, wastewater, normatively purified at treatment facilities, amounted to $37 \%$, the wastewater without definition of quality class dumped into surface water bodies equaled 5\%. Significant reduction of the surface water intake led to a corresponding reduction of wastewater discharge of different categories and irrecoverable losses, but did not improve the hydroecological situation in the river basin [South Ukrainian NPP].

The Southern Bug River Basin is characterized by a chronic deficit of water resources, because the water supply per each citizen over recent years is only $880 \mathrm{~m}^{3} /$ year. Total resources of surface runoff in 2019 were $1.44 \mathrm{~km}^{3}$. State Agency for Water Resources of Ukraine based on article 45 of the Water Code of Ukraine issued a official statement that for the first time in 120 years, the rights and conditions of water use, in particular water discharges through dams HPS, may be restricted or changed due to abnormal autumn and winter 2019-2020. It was stated that in the case of such measures, the priority would be to ensure the drinking and household needs of the population [Water management situation]. The position of the water agency is based on the data of the Ukrainian Hydrometeorological Center about the low water content in most rivers of Ukraine. There was no spring flood this year on Ukrainian rivers, and low water content could lead to drying up of small streams [Ukrainian Hydrometeorological Center].

According to the definition of the International Community, the national threshold for the minimum water supply required to meet the needs of 
agriculture, industry, energy and environmental conservation in per capita terms is $1700 \mathrm{~m}^{3} /$ year. A decrease in this indicator to $1000 \mathrm{~m}^{3} /$ year indicates a shortage of water resources, and if the indicator does not exceed $500 \mathrm{~m}^{3}$, informs about their absolute deficit. Ukraine belongs to the region of the planet where the mean annual air temperature has changed at the fastest rates over the past 30 years. The mean annual air temperature in 2019 was $2.0-3.3^{\circ} \mathrm{C}$ above the norm (1961-1990) and $1.5-2.0^{\circ} \mathrm{C}$ above the multi-year averages values (1981-2010). The amount of precipitation in 2019 in the country was, on average, 13\% lower, whereas in the forest-steppe regions - lower by 27\% [Ukrainian Hydrometeorological Center]. The analysis of the water content of the Southern Bug River over the past 12 years indicates a significant decrease in the natural runoff of the river. The regulation of the basin against the background of global climatic changes leads to an increase in irreversible losses of surface water for evaporation, to a violation of the hydrochemical regime of the river and to a change of the water quality [Resolution of the seminar, 2017].

The purpose of the paper was to conduct the surface water quality assessment of the Southern Bug River Basin by complex indices for different water users, as well as definition of the ability of water body to self-purification and capability of restoration in a changing climate.

\section{MATERIALS AND METHODS}

Detailed studies of the natural and ecological potential of the water resources of the Southern Bug River Basin were carried out by specialists of the Institute of Hydrobiology of the National Academy of Sciences of Ukraine in 2010-2011 [Afanasyev et al., 2012]. Scientists described the hydrochemical regime of the river channel, assessed the ecological state of the river, as well as established the background values of total nitrogen and phosphorus for the upper, middle and lower course of the river. Ukrainian scientists [Magas et al., 2013] carried out a characterization of the anthropogenic load on the water resources of the Southern Bug River basin within the Mykolaivska region in 2013. They assessed the water quality in the rivers of the Southern Bug Basin on the basis of an integral ecological index. The assessment of the water quality of the Southern Bug River in the area of powerful water intakes in the Vinnytska region was carried out by specialists from the V. Dumansky Institute of Colloidal Chemistry and Water Chemistry of the National Academy of Sciences of Ukraine [Yezlovetska et al., 2015]. The published results of previous studies of surface water quality in the Southern Bug River Basin refer to the period 2010-2015; therefore, to ensure the rational use of water resources, the current state of water quality in the Southern Bug River was assessed.

Monitoring of the river conditions in Ukraine is carried out by State monitoring entities [The Ministry of Environment Protection and Natural Resources, The State Ecological Inspectorate, The State Agency for Water Resources, The Hydrometeorological Service, The Ministry of Health]; each has its own observation points network, own methods and indicators that are controlled. At the same time, even if the sampling locations and control indicators coincide, the data obtained by different monitoring subjects practically do not coincide and may differ by more than 2 orders of magnitude [Afanasyev et al., 2012]. The biological control over the state of surface water resources is carried out by the Hydrometeorological Service and hydrobiological stations of the National Academy of Sciences of Ukraine according to a limited number of tropho-saprobiological indicators. The exploitation of water resources should be carried out on the basis of reliable data from a stationary monitoring network [Odnorih et al., 2020] using modern methods for assessing the state of water bodies [Directive, EU Water Framework, 2006] and according to the basin principle [Pohrebennyk et al., 2020, Directive, EU Water Framework, 2006].

The number of parameters that are regulated by various monitoring entities is quite large; therefore, it becomes necessary to generalize the information on the quality of surface water and the ecological state of a water body on the basis of complex indicators. Complex indices, which are calculated according to hydrochemical parameters, are convenient to use, characterizing the state of the aquatic environment as a whole, taking into account its properties and composition. They provide quick obtaining of information about the water quality and the state of the hydroecosystem, which allows making quick decisions on water resources management. Assessment of the water quality by hydrochemical parameters provides the calculation for all indicators of water quality or for their parts. The sequence of the assessment 
consists of two stages: at the first stage, the value of the index is calculated, and at the second, according to the calculated values of the index and according to the quality scale, a verbal characteristic of water is given [Yurasov et al., 2012].

The analytical monitoring data of surface water of the State Agency for Water Resources of Ukraine within the Vinnytska and Mykolaivska regions (monthly sampling by the 12 parameters) for the year 2019 was used to assess the water quality of the Southern Bug River [Water management situation]. We have processed the observational data on points of supervisions of water: 1 - the Southern Bug River - city Khmilnyk (652 km from the mouth); 2 - the Southern Bug River - city Vinnytsia (582 km from the mouth); 3 - the Southern Bug River - city Voznesensk (97 km from the mouth).

Then, we performed a water quality assessment by the complex indices, calculated by hydrochemical parameters: index of water pollution (IPW), modified index of water pollution (MIPW), combinatorial index of water pollution (CIPW) for different water users (for drinking, fishery, cultural, and recreational needs) (Table 1) according to the surface water quality standards [State sanitary norms and rules "Hygienic requirements for drinking water intended for human consumption" 2.2.4-171-10, Sanitary rules and norms for the protection of surface water from pollution 4630-88].

The summary results of assessing the water quality of the Southern Bug River by complex indices (IPW, MIPW, CIPW) demonstrate significant discrepancies, which allows us to assert that it is impossible to reliably recommend one of the above-mentioned methods to substantiate the possibility of using water by a particular water user. In addition, only the combinatorial index of water pollution (CIPW) of the listed complex indices, takes into account the effect of the total action of pollutants.

The method of integral assessment of water quality, which also takes into account the effect of the total action of pollutants, was proposed by Bardova, Fedorenko. It is based on the calculation of a complex index - the coefficient of pollution $\chi$ [Bordova, 2006]:

$$
\chi=\sum\left[\left(N_{i} / C_{i, d}\right) \varphi(i)\right] / \sum \varphi(i)
$$

where: $N_{i}$ - pollution indicator value;

$i$ - number of pollution indicator in a rank sequence of $m$ indicators;

$C_{i, d}$ - standard indicator (maximum permissible concentrations $(M P C)$ ); $\varphi(i)=i / 2^{i-1}-$ weight function; $\sum \varphi(i)-$ given number of indicators.

The following indicators of pollution are accepted as the main ones with the corresponding rank sequence $(i)$ : Biological oxygen demand $\left(\mathrm{BOD}_{5}\right)(i=1)$; Total ammonium $(i=2)$; Petroleum hydrocarbons $(i=3)$; Dissolved oxygen $(i=4)$.

The ranks of other indicators are set by experts or through ratio checks $N_{i} / C_{i, d}$.

A certification scale is used to assess the degree of pollution of the aquatic environment, depending on the value of the coefficient $\chi$ (Table 2) [Bordova, 2006]:

The calculation method of complex index of the ecological state [Shakhman et al., 2018, Timchenko, 2002] allows us to quickly determine the ecological state of the aquatic ecosystem by the

Table 1. Water quality assessment of the Southern Bug River by the complex indices

\begin{tabular}{|c|c|c|c|c|c|c|}
\hline \multirow{2}{*}{$\begin{array}{l}\text { Gauge } \\
\text { station }\end{array}$} & \multicolumn{6}{|c|}{ Assessment of the pollution degree } \\
\hline & \multicolumn{2}{|r|}{ IPW } & \multicolumn{2}{|c|}{ MIPW } & \multicolumn{2}{|r|}{ CIPW } \\
\hline \multicolumn{7}{|c|}{ fishery standards } \\
\hline 1 & 8.62 & very dirty & 16.6 & catastrophically dirty & 30 & dirty \\
\hline 2 & 8.54 & very dirty & 16.0 & catastrophically dirty & 30 & dirty \\
\hline 3 & 7.48 & very dirty & 14.0 & catastrophically dirty & 40 & very dirty \\
\hline \multicolumn{7}{|c|}{ drinking standards } \\
\hline 1 & 1.84 & slightly contaminated & 3.79 & moderately contaminated & 36 & dirty \\
\hline 2 & 1.91 & slightly contaminated & 4.00 & moderately contaminated & 35 & dirty \\
\hline 3 & 1.66 & slightly contaminated & 3.00 & moderately contaminated & 29 & dirty \\
\hline \multicolumn{7}{|c|}{ cultural and recreational standards } \\
\hline 1 & 0.69 & sufficient clean & 2.43 & slightly contaminated & 19 & moderately dirty \\
\hline 2 & 0.79 & sufficient clean & 2.00 & slightly contaminated & 27 & dirty \\
\hline 3 & 0.68 & sufficient clean & 2.00 & slightly contaminated & 28 & dirty \\
\hline
\end{tabular}


Table 2. Integral assessment of water quality

\begin{tabular}{|c|l|}
\hline $\begin{array}{c}\text { Water coefficient of } \\
\text { pollution } \chi\end{array}$ & Qualitative assessment of pollution \\
\hline Less than 1.00 & sufficient clean \\
\hline $1-1.99$ & slightly contaminated \\
\hline $2-2.99$ & moderately contaminated \\
\hline $3-3.99$ & dirty \\
\hline $4-5.00$ & very dirty \\
\hline More than 5.00 & catastrophically dirty \\
\hline
\end{tabular}

hydrochemical indicators. It also allows - according to the ecological state complex indices of the water body - to assess its ability to self-purification potential and capability of restoration (ecological reliability), to analyze the ecological sustainability of the river and to take into account the effect of the total action of substances [Shakhman et al., 2017, Shakhman et al., 2018]. Complex index of the ecological state (CIES) is formed on the basis of existing standards and also includes maximum permissible concentrations (MPC).

For the water bodies which are used for the fishery, the mean value of CIES is calculated by the formula:

$$
\text { CIES }_{\text {mean }}=\frac{1}{m} \sum_{i=1}^{m} \text { CIES }_{i}
$$

where: $m$ - number of water quality indices blocks (values $\mathrm{CIES}_{i}$ ).

From the $m$ blocks of water quality indices, the first includes the indices that do not have the effect of total action (summation); the remaining blocks include indices that have this effect [Shakhman et al., 2018, Timchenko, 2002]. According to the sanitary norms, the effect of total action is possessed by the substances of the first and second classes of danger with the equal limiting indices of harmfulness $(L I H)$. According to the fishery norms substances with the equal $L I H$ without taking into account the classes of danger are analyzed.

The ecological state of a water body is classified as follows [Shakhman et al., 2018, Timchenko, 2002]:

- if $C I E S_{\min }<0$ and $C I E S_{\text {mean }}<0$ then the ecological state of the river area is estimated as unsteady;

- if $C I E S_{\min }<0$ and $C I E S_{\text {mean }}>0$ then the ecological state of water is estimated on average as stable with sources of instability;

- if $C I E S_{\text {min }}>0$ and $C I E S_{\text {mean }}>0$ then the ecological state of water is estimated as stable.
In the qualification of the ecological state according by the first two points it is necessary to carry out the environmental protection activities in the ecosystem. The obtained results allow carrying out an assessment of the ecological reliability of the ecosystem [Shakhman et al., 2018, Timchenko, 2002]. Ecological reliability (ER) is the ability of the ecosystem's state to perform relatively complete processes of self-purification potential and capability of restoration.

The probability of a stable state of the river is called ecological reliability (ER), which is determined by the formula:

$$
E R=1-\chi^{2} /\left(2 N-M+0.5 \chi^{2}\right)
$$

where: $\chi^{2}$ - value of the function "chi-square" with the confidence probability assumed equal to 0.9 [Gmurman, 1979]; $N$ - total number of values $C I E S_{\text {mean }}$; $M$ - number of values $C I E S_{\text {mean }}$ which is less then the critical, zero value.

Distribution probability of "chi-squared" is recognizing right in connection with the fact that usually the number of surveyed sections of the river is small. For a large value of $N$, the "chi-squared" distribution reduces to a normal distribution [Shakhman et al., 2018, Timchenko, 2002]. On the basis of the fact that complex technical systems are considered reliable at a reliability level of $0.90-0.95$, the following qualification of reliability levels is used with a confidence level of 0.9: a high level (ER $\geq 0.9)$, an acceptable level $(0.9>\mathrm{ER} \geq 0.8)$, a low level $(\mathrm{ER} \geq 0.8)$ [Shakhman et al., 2018, Timchenko, 2002].

\section{RESULTS AND DISCUSSIONS}

The data of the analytical monitoring of surface waters of the Southern Bug River for 2019 (Biological oxygen demand $\left(\mathrm{BOD}_{5}\right)$, Dissolved oxygen, Suspended solids, Total ammonium, Nitrites, Nitrates, Chlorides, Sulphates, Synthetic surfactants (SAS), Phosphates, Chemical oxygen demand (COD), Petroleum hydrocarbons) [Water management situation] were systematized in tables of mean annual values of the pollutants concentrations along the gauge stations: $1-$ the Southern Bug River - city Khmilnyk $(652$ km from the mouth); 2 - the Southern Bug River - city Vinnytsia (582 km from the mouth); 3 the Southern Bug River - city Voznesensk (97 km 
from the mouth). Further, a comparative analysis of the values of the concentrations of pollutants in time and in space (along the river stream) was carried out.

In 2019, the excess of concentrations of pollutants relative to the standards of all categories of water users (for drinking, fishery, cultural, and recreational needs) for the entire section of the river was observed according to 5 hydrochemical parameters $\left(\mathrm{BOD}_{5}\right.$, Total ammonium, Nitrites, SAS, COD). Biogenic substances play a significant role in the life of living organisms (Total ammonium, Nitrites, Nitrates and Phosphates). Throughout the studied section of the river $(555 \mathrm{~km})$, the content of Total ammonium exceeded the permissible norms and amounted to: $0.76 \mathrm{mg} / \mathrm{dm}^{3}$ (c. Khmilnyk), $1.12 \mathrm{mg} / \mathrm{dm}^{3}$ (c. Vinnytsia), $1.04 \mathrm{mg} / \mathrm{dm}^{3}$ (c. Voznesensk), (which corresponds to III (moderately contaminated) and IV (dirty) classes of water quality [Gritsenko et al. 2012].

Organic matter is important in biochemical processes and, to some extent, determines the biological productivity of surface waters and water quality. Their content is determined by indirect indicators: permanganate and bichromate oxidizability (COD) and Biological oxygen demand $\left(\mathrm{BOD}_{5}\right)$. In the water of the Southern Bug River in 2019, a significant content of organic compounds was observed. COD exceeded MPC throughout the stretch of a river: $37.5 \mathrm{mg} / \mathrm{dm}^{3}$ (c. Khmilnyk), $34.0 \mathrm{mg} / \mathrm{dm}^{3}$ (c. Vinnytsia), $25.02 \mathrm{mg} / \mathrm{dm}^{3}$ (c. Voznesensk), which corresponds to III (moderately contaminated) and II (slightly contaminated) water quality classes.

The indicator of the SAS toxicological block in the surface water of the Southern Bug River Basin in 2019 had the highest values downstream from c. Vinnytsia $\left(\max 7.90 \mathrm{mg} / \mathrm{dm}^{3}\right)$. For the entire investigated section of the river, the mean annual SAS values correspond to V (very dirty) water quality class.

In previous studies, a software product was developed that made it possible to implement a visual model of the distribution of pollutants between the observation places along the length of the Dnieper River [Bystriantseva et al., 2019]. On the basis of the input data, the program allows obtaining a gradient coloring of the river bed in a color range that corresponds to a certain category of water quality, which facilitates swift decisionmaking in the process of water resources day-today management. The examples of the spatial distribution (along the river stream of the Southern Bug River) of the mean annual concentrations of some pollutants (2019), which were analyzed above, are presented in Figure 1.

Comparative analysis of mean annual concentrations of pollutants in 2019 in the river section c. Khmilnyk - c. Vinnytsia with the results of research in 2015 [Odnorih et al., 2020] shows that the main hydrochemical parameters of the Southern Bug River have changed over a wide range (Table 3 ).

The surface water quality of the Southern Bug River in the river section c. Khmilnyk - c. Vinnytsia in terms of biogenic indicators for 5 years has changed as follows: for Total ammonium from class III (4 category) "slightly contaminated" to IV class (6 category) "dirty"; by Nitrites - from I class (1 category) "very clean" to V class (7 category) "very dirty"; by Nitrates - from class II (3 category) "sufficient clean" to IV class (6 category) "dirty"; by Phosphates - from III class (4 category) "slightly contaminated" to V class (7 category) "very dirty". Such an assessment of water quality allows for quick decision-making in the process of short-term water resources management.

In order to obtain the information on the ecological state of the river, on the tendency of spatio-temporal changes in the state of water under the influence of natural and anthropogenic factors, substantiation of the long-term measures for the rational use of a water body, a complex assessment of water quality is required. A complex assessment also can be used to carry out a comparative analysis of the state of surface water of different rivers.

At the next stage of the study, an integral assessment of water quality was carried out based on the calculation of a complex index - the pollution coefficient $\chi(1)$. An example of a calculation for the Southern Bug River - city Khmilnyk in accordance with the fishery standards (as the most sensitive to changes of the ecological state of the river) is given in Table 4.

The summary results of the integral water quality assessment of the Southern Bug River for 2019 , in accordance with the surface water quality standards intended for different water users (for drinking, fishery, cultural, and recreational needs), are presented in Table 5.

Further, the ecological state of the Southern Bug River for 2019 was assessed according to the complex indices of the ecological state (2), which 


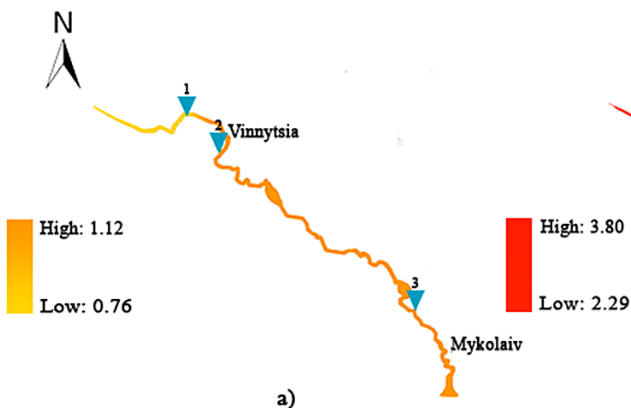

a)

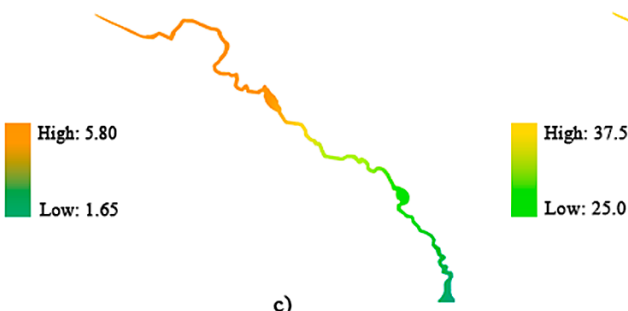

c)

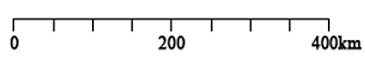

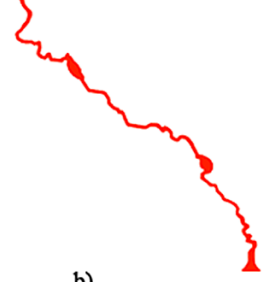

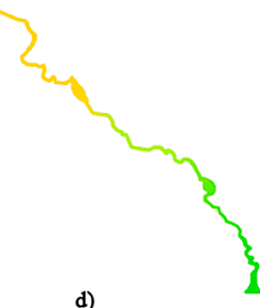

Fig. 1. Ecological state of the surface waters of the of the Southern Bug River by hydrochemical parameters, $\mathrm{mg} / \mathrm{dm}^{3}$ : a - Total ammonium, $\mathrm{b}-$ Nitrites, $\mathrm{c}-\mathrm{BOD}_{5}, \mathrm{~d}-\mathrm{COD}$

includes the analysis of the ecological sustainability and ecological reliability (3) of the water body, in accordance with the fishery standards, as the most sensitive to the changes in the ecological state of the river. An example of assessment of the ecological state of the Southern Bug River using CIES at the Southern Bug River - city Vinnytsia gauge station for the observation year 2019 is shown in Table 6.

The summary results of the ecological state assessment of the Southern Bug River in space (along the river stream) of the year 2019 based on complex index of the ecological state (CIES) with the fishery standards are presented in Table 7

The ecological state of the Southern Bug River is assessed as unsteady. The changes in the quantitative values of the mean and minimum coefficients show some improvement in the water quality downstream of the river. This corresponds to the general trend of calculations according to the complex indices given above, but, unfortunately, does not change the assessment of the

Table 3. Assessment of water quality in the section of the Southern Bug River (c. Khmilnyk - c. Vinnytsia) by nutrients for 2010-2019

\begin{tabular}{|c|c|c|c|c|}
\hline \multirow[b]{2}{*}{ Parameter } & \multicolumn{4}{|c|}{ Water quality assessment by ecological classification } \\
\hline & $\begin{array}{l}\text { Value, } \\
\mathrm{mg} / \mathrm{dm}^{3}\end{array}$ & Water quality class & $\begin{array}{l}\text { Value, } \\
\text { mg/dm }\end{array}$ & Water quality class \\
\hline Year & \multicolumn{2}{|c|}{2015 (Odnorih et al., 2020) } & \multicolumn{2}{|r|}{2019} \\
\hline \multicolumn{5}{|c|}{ the Southern Bug River - c. Khmilnyk } \\
\hline Total ammonium & 0.46 & slightly contaminated & 0.76 & moderately contaminated \\
\hline Nitrites & 0.019 & very clean & 3.80 & very dirty \\
\hline Nitrates & 0.35 & sufficient clean & 2.19 & dirty \\
\hline Phosphates & 0.072 & slightly contaminated & 0.58 & very dirty \\
\hline \multicolumn{5}{|c|}{ the Southern Bug River - c. Vinnytsia } \\
\hline Total ammonium & 0.85 & moderately contaminated & 1.12 & dirty \\
\hline Nitrites & 0.022 & very clean & 3.72 & very dirty \\
\hline Nitrates & 0.39 & sufficient clean & 2.40 & dirty \\
\hline Phosphates & 0.091 & slightly contaminated & 1.41 & very dirty \\
\hline
\end{tabular}


Table 4. Integral assessment of water quality of the Southern Bug River - c. Khmilnyk by the pollution coefficient $\chi$ by the fishery standards for 2019

\begin{tabular}{|c|c|c|c|c|c|c|c|}
\hline \multirow[b]{2}{*}{ Parameter } & \multirow[b]{2}{*}{$C_{i} / M P C_{i}$} & \multicolumn{3}{|c|}{ With priorities } & \multicolumn{3}{|c|}{ No priorities } \\
\hline & & rank & $\varphi(i)$ & $\varphi(i) C_{i} / M P C_{i}$ & rank & $\varphi(i)$ & $\varphi(i) C_{i} / M P C_{i}$ \\
\hline $\mathrm{BOD}_{5}$ & 1.93 & 1 & 1.000000 & 1.93000 & 3 & 0.750000 & 1.44475 \\
\hline $\begin{array}{l}\text { Dissolved } \\
\text { oxygen }\end{array}$ & 0.74 & 4 & 0.500000 & 0.37000 & 6 & 0.187500 & 0.13875 \\
\hline $\begin{array}{l}\text { Suspended } \\
\text { solids }\end{array}$ & 0.54 & 8 & 0.062500 & 0.03375 & 7 & 0.109375 & 0.05906 \\
\hline Total ammonium & 1.52 & 2 & 1.000000 & 1.52000 & 5 & 0.312500 & 0.47500 \\
\hline Nitrites & 47.5 & 5 & 0.312500 & 14.84375 & 1 & 1.000000 & 47.50000 \\
\hline Nitrates & 0.05 & 12 & 0.005859 & 0.00029 & 11 & 0.010742 & 0.00537 \\
\hline Chlorides & 0.11 & 11 & 0.010742 & 0.00118 & 10 & 0.019531 & 0.00215 \\
\hline Sulphates & 0.30 & 9 & 0.035156 & 0.01054 & 8 & 0.06250 & 0.01875 \\
\hline SAS & 46.0 & 6 & 0.187500 & 8.62500 & 2 & 1.000000 & 46.00000 \\
\hline COD & 1.88 & 7 & 0.109375 & 0.20562 & 4 & 0.500000 & 0.94000 \\
\hline Phosphates & 0.17 & 10 & 0.019531 & 0.00332 & 9 & 0.035156 & 0.00598 \\
\hline $\begin{array}{l}\text { Petroleum hydro- } \\
\text { carbons }\end{array}$ & 0.00 & 3 & 0.750000 & 0.00000 & 12 & 0.005859 & 0.00000 \\
\hline \multicolumn{3}{|c|}{$\sum$} & 3.993163 & 27.54345 & & 3.993163 & 96.59256 \\
\hline \multicolumn{4}{|c|}{$\begin{array}{c}\chi=27.54345 / 3.993163=6.90 \\
\text { (catastrophically dirty) }\end{array}$} & \multicolumn{4}{|c|}{$\begin{array}{c}\chi=96.59256 / 3.993163=24.2 \\
\text { (catastrophically dirty) }\end{array}$} \\
\hline
\end{tabular}

ecological state of the river and determines the urgent need for environmental protection measures in the ecosystem.

A slight improvement in the water quality can be explained by the possible accumulation of pollutants in numerous reservoirs located throughout the entire study area, and a significant sinuosity of the river bed upstream of c. Voznesensk. An increase in turbulent water exchange and a decrease in the concentration of pollutants due to an increase in the water content is also possible, but it is regulated exclusively artificially in accordance with the operating regime of water management complexes located upstream of the river.

Further, an assessment of the ecological reliability (3) of the Southern Bug River for 2019 in space (along the river stream) was made. The ecological reliability (ER) value is 0.77 , which corresponds to a low level of self-purification potential and capability of restoration.

A comparative analysis of the results of the water quality assessment of the Southern Bug River by complex indices (Tables $1,5,7)$ makes it possible to recommend with a high degree of

Table 5. The summary results of the integral water quality assessment of the Southern Bug River for 2019

\begin{tabular}{|c|c|l|c|l|}
\hline \multirow{2}{*}{ Gauge station } & \multicolumn{5}{|c|}{ Assessment of the degree of pollution } \\
\cline { 2 - 5 } & \multicolumn{5}{|c|}{ The fishery standards } \\
\hline \multicolumn{5}{|c|}{ No priorities } \\
\hline 1 & 6.90 & catastrophically dirty & 24.2 & catastrophically dirty \\
\hline 2 & 6.85 & catastrophically dirty & 23.4 & catastrophically dirty \\
\hline 3 & 3.72 & dirty & 11.5 & catastrophically dirty \\
\hline \multicolumn{5}{|c|}{ Drinking standards } \\
\hline 1 & 1.96 & slightly contaminated & 5.02 & catastrophically dirty \\
\hline 2 & 2.05 & moderately contaminated & 4.91 & very dirty \\
\hline 3 & 1.22 & slightly contaminated & 2.55 & moderately contaminated \\
\hline \multicolumn{5}{|c|}{ Cultural and recreational standards } \\
\hline 1 & 1.50 & slightly contaminated & 3.18 & dirty \\
\hline 2 & 1.81 & slightly contaminated & 4.14 & very dirty \\
\hline 3 & 0.93 & sufficient clean & 1.55 & slightly contaminated \\
\hline
\end{tabular}


Table 6. Assessment of water quality of the Southern Bug River - city Vinnytsia by CIES in accordance with the fishery standards of the year 2019

\begin{tabular}{|c|c|c|c|c|c|c|}
\hline LIH & Parameter & $\underset{\mathrm{mg} / \mathrm{dm}^{3}}{\mathrm{C}_{\mathrm{C}^{3}}}$ & $\begin{array}{l}\mathrm{MPC} \\
\mathrm{mg} / \mathrm{dm}^{3}\end{array}$ & $M P C-C_{i}$ & IES & CIES \\
\hline \multirow{3}{*}{ General health } & Suspended solids & 10.0 & 20.0 & 10.0 & 0.5 & \\
\hline & $\mathrm{BOD}_{5}$ & 5.1 & 3.0 & -2.1 & -0.7 & \\
\hline & Dissolved oxygen & 7.8 & $>6.0$ & 1.8 & 0.3 & \\
\hline \multicolumn{5}{|c|}{$\sum$} & 0.1 & 0.033 \\
\hline \multirow{3}{*}{ Toxicological } & Total ammonium & 1.12 & 0.5 & - & 2.24 & \\
\hline & Nitrites & 3.72 & 0.08 & - & 46.5 & \\
\hline & SAS & 4.39 & 0.1 & - & 43.9 & \\
\hline \multicolumn{5}{|c|}{$\sum$} & 92.64 & -91.64 \\
\hline \multirow{4}{*}{ Sanitary-toxicological } & Chlorides & 32.2 & 300 & - & 0.107 & \\
\hline & Sulphates & 29.9 & 100 & - & 0.292 & \\
\hline & Nitrates & 2.4 & 40.0 & - & 0.06 & \\
\hline & Phosphates & 1.41 & 3.5 & - & 0.403 & \\
\hline \multicolumn{5}{|c|}{$\sum$} & 0.862 & 0.138 \\
\hline Fishery & $\begin{array}{l}\begin{array}{l}\text { Petroleum hydro- } \\
\text { carbons }\end{array} \\
\end{array}$ & - & 0.05 & - & - & - \\
\hline
\end{tabular}

probability for a comprehensive assessment of the water quality of the Southern Bug River methods that take into account the effect of the total action of pollutants in developing long-term measures and making strategic decisions on the rehabilitation of a water body. Namely, it is recommended to perform an assessment based on a combinatorial index of water pollution, an integral assessment of water quality and an assessment based on a complex index of the ecological state.

The ongoing global climate change is rather complex. There are quite a number of scenarios for the development of the situation in which, due to global warming, the climate in southern Ukraine will become drier and warmer, with warm and humid winters. Therefore, today it is necessary to create the water management complexes that will ensure the rational use, conservation and restoration of water resources.

Despite the fact that the Southern Bug River is not a transboundary river, adaptation to climate change requires a multilateral approach to determining the required data in accordance with the principles of integrated water resources management. The Guidance on Water and Climate Adaptation [Guidance on Water and Climate Adaption] emphasizes the critical importance of the availability of the information required for disaster risk reduction, environmental and social vulnerability assessment. On the other hand, the surface waters of the Southern Bug River Basin are formed exclusively on the territory of our country, and Ukraine has all the possibilities and levers for the rehabilitation and restoration of a water body of national importance.

Table 7. Assessment of ecological state of the Southern Bug River in space (along the river stream) of the year 2019

\begin{tabular}{|c|c|c|}
\hline \multirow{3}{*}{ Gauge station } & \multicolumn{2}{|c|}{ Complex index of the ecological state (CIES) } \\
\hline & $\min$ & mean \\
\hline & \multicolumn{2}{|c|}{ ecological state of a water body } \\
\hline \multirow{2}{*}{ The Southern Bug River - city Khmilnyk } & -31.2 & -94.0 \\
\hline & \multicolumn{2}{|c|}{ unsteady } \\
\hline \multirow{2}{*}{ The Southern Bug River - city Vinnytsia } & -30.5 & -91.6 \\
\hline & \multicolumn{2}{|c|}{ unsteady } \\
\hline \multirow{2}{*}{ The Southern Bug River - city Voznesensk } & $-14,7$ & -44.5 \\
\hline & \multicolumn{2}{|c|}{ unsteady } \\
\hline
\end{tabular}




\section{CONCLUSIONS}

The assessment of the surface water quality of the Southern Bug River basin in time and space was carried out. The surface water quality of the Southern Bug River in the c. Khmilnyk - c. Vinnytsia river section in terms of biogenic indicators from 2015 to 2019 changed as follows: for Total ammonium - from III class "slightly contaminated" to IV class "dirty"; according to Nitrites from I class "very clean" to V class "very dirty"; by Nitrates - from II class "sufficient clean" to IV class "dirty"; by Phosphates - from III class "slightly contaminated" to V class "very dirty".

The results of water quality assessing of the Southern Bug River in 2019 based on complex indices in accordance with the fishery standards as the most sensitive to the changes of the ecological state of the river are as follows: based on CIPW - mostly "dirty"; - mostly "catastrophically dirty"; CIES "the ecological state of the object is unstable", the quantitative indicator of ecological reliability is below 0.8 , which corresponds to a low level of selfpurification potential and capability of restoration of the water body. Therefore, with a certain degree of probability, it can be argued that the use of surface waters of the Southern Bug River Basin for drinking, fishery, cultural, and recreational needs is associated with certain environmental risks, and for the hydroecosystem it is necessary to carry out the environmental protection measures.

The results of the study can be used in the development of a strategy for water resources management in the Southern Bug River Basin, for assessing and predicting the ecological state of the river in the context of water management transformations and climate change, with scientific substantiation of measures aimed at protecting and rational use of the surface water in the Southern Bug River Basin.

\section{REFERENCES}

1. Afanasyev S.O., Vasilchuk T.O., Letytska O.M., Bilous O.P. 2012. Assessment of the ecological state of the Southern Bug River in accordance with the requirements of the EU Water Framework Directive. NVP “Interservice LLC”, Kyiv, 29. (in Ukrainian).

2. Basin Administration of Water Resources of the Southern Bug River. https://buvrpb.davr.gov.ua/ vodni-resursy/analiz-zabezpechennia-vodnymyresursamy-naselennia-i-haluzei-ekonomiky (access: 28.07.2020). (In Russian).
3. Bordova V.G. (ed.). 2006. Hygiene and ecology. Vinnytsia: New Book. 720 (in Ukrainian).

4. Bystriantseva A., Shakhman I., Bystriantsev M. 2019. Spatio-temporal representation of the ecological state of the surface waters of the Lower Section of the Dnieper River using GIS technologies. Proc. ICTERI 2019, I (2387).

5. Directive, EU Water Framework. 2006. “60/EC Definitions of Main Terms".

6. Gmurman V.E. 1979. Guide for solving problems in probability theory and mathematical statistics. M: Vysshaya shkola, 400. (in Russian).

7. Gritsenko A.V., Vasenko O.G., Vernichenko G.A. et al. 2012. Methodology of ecological assessment of surface water quality by appropriate categories. Kh. UkrNIEP. (in Ukrainian).

8. Guidance on Water and Climate Adaption. UNECE: Sustainable development goals. https://www.unece. org/index.php?id=11658 (access: 28.08.2020).

9. Magas N.I., Trokhimenko A.G. 2013. Estimation of modern anthropogenic load on the Southern Bug river basin. Ecological safety, 2(16), 48-52. (in Ukrainian).

10. Odnorih Z., Manko R., Malovanyy M., Soloviy Kh. 2020. Results of surface water quality monitoring of the Western Bug River basin in Lviv region. Journal of Ecological Engineering, 21(3), 18-26.

11. Pohrebennyk V., Kulyk M., Bihun I. 2020. Evaluation of the Pollution Level of Surface and Waste Water. Journal of Ecological Engineering, 21(5), 180-188.

12. Regional office of water resources in the Mykolaivska region. https://mk-vodres.davr.gov.ua/water_resources (access: 28.07.2020). (In Russian).

13. Regional report on the state of the environment in the Mykolaivska region in 2018. 2019. Mykolaiv, 175. (in Ukrainian).

14. Regional report on the state of the environment in the Vinnytska region in 2018. 2019. Vinnytsia, 229. (in Ukrainian).

15. Resolution of the seminar "Industrial Program for the Development of Hydropower for the Period up to 2026: Regional Level (the Southern Bug Basin) - the point of view of experts and communities". 2017. Mykolaiv, 15.09.2017. 6. (in Ukrainian).

16. Sanitary rules and norms for the protection of surface water from pollution 4630-88. https://zakon. rada.gov.ua/laws/show/v4630400-88\#Text / (access: 20.07.2020).

17. Shakhman I.A., Bystriantseva A.N. 2017. Assessment of Ecological State and Ecological Reliability of the Lower Section of the Ingulets River. Hydrobiological Journal. USA. 53(5), 103-109. DOI: 10.1615/HydrobJ.v53.i5.110.

18. Shakhman, I.A., Bystriantseva, A.N. 2018. Assessment of ecological state and ecological reliability of the Lower section of the Dnieper River. Proc. 18th 
International Multidisciplinary scientific GeoConference SGEM, 113-119.

19. State sanitary norms and rules "Hygienic requirements for drinking water intended for human consumption" 2.2.4-171-10. https://zakon. rada.gov.ua/-laws/show/z0452-10\#Text/ (access: 20.07.2020). (in Ukrainian).

20. South Ukrainian NPP. https://www.sunpp.mk.ua (access: 08.04.2020). (in Ukrainian).

21. Timchenko Z.V. 2002. Water resources and the ecological state of the small rivers of the Crimea. Simferopol: Dolya, 152 (in Ukrainian).

22. Ukrainian Hydrometeorological Center. https://meteo.gov.ua/ua/33345/hydrology-/hydr_vodopillya/ (access: 25.05.2020). (in Ukrainian).

23. Water management situation. State Agency of Water Resources of Ukraine. https://www.davr.gov. ua/vodogospodarska-obstanovka/page-10 (access: 10.02.2020). (in Ukrainian).

24. Yezlovetska I.S., Shunkov V.S., Bulanyuk S.M. 2015. Assessment of water quality of the Southern Bug in places of powerful drinking water intakes of Vinnytska region. Water and water treatment technologies. Scientific and technical news. 2(17), 22-39. (in Ukrainian).

25. Yurasov S.M., Safranov T.A., Chugai A.V. 2012. Assessment of natural water quality. Odessa: Ecology. 168 (in Ukrainian). 